\title{
Uji Validitas Pada Tes Proyeksi Gambar Berstimulus: The Doodle Test
}

\author{
Fadillah $^{1}$, Medianta Tarigan ${ }^{2}$ \\ ${ }^{1}$ Program Studi Desain Komunikasi Visual, Institut Teknologi Bandung, Bandung \\ ${ }^{2}$ Departemen Psikologi, Universitas Pendidikan Indonesia, Bandung \\ fadillah@itb.ac.id
}

\begin{abstract}
Abstrak
Penggunaan alat ukur psikologis berbasis gambar menjadi salah satu tantangan di bidang psikologi karena masih terbatasnya penelitian akademis terkait validitas alat tersebut. Namun dalam kenyataannya, tes gambar proyektif dianggap sangat bermanfaat dalam mengungkap profil kepribadian individu. The Doodle Test merupakan alat ukur psikologi yang juga termasuk dalam tes gambar proyektif. Kebaruan dan kemudahan administrasinya membuat alat ini menarik bagi para praktisi untuk menggunakannya di lapangan. Hingga saat ini, masih sedikit penelitian terkait pengujian psikometrik The Doodle Test. Penelitian kali ini bertujuan untuk melakukan uji validitas konkuren terhadap The Doodle Test dengan melihat korelasinya dengan alat tes serupa yang sudah ada yaitu The Wartegg Zeichen Test. Sebanyak 103 hasil interpretasi kuantitatif The Doodle Test dan The Wartegg Zeichen Test dianalisis dengan menggunakan teknik korelasi product moment. Hasil analisis menunjukkan bahwa The Doodle Test memiliki korelasi yang signifikan dengan The Wartegg Zeichen Test sehingga dapat dikatakan valid dalam mengukur aspek-aspek kepribadian sebagaimana yang diukur oleh The Wartegg Test.
\end{abstract}

Kata kunci: korelasi; tes proyeksi; The Doodle Test; The Wartegg Zeichen Test; validitas konkuren

\begin{abstract}
The use of drawing-based psychological tools is one of the challenges in the psychology because of the limited academic research related to the validity of these tools. But in the other side, projective drawing tests are considered very useful in revealing individual personality profiles. The Doodle Test is a psychological measurement tool that is also included in a projective drawing test. Its novelty and ease of administration make this tool attractive to many practitioners. Until now, there has been little research related to the psychometric testing of The Doodle Test. This research aims to test the concurrent validity of The Doodle Test by looking its correlation with a similar existing test, namely The Wartegg Zeichen Test. A total of 103 results of the quantitative interpretation of The Doodle Test and The Wartegg Zeichen Test were analyzed using the product moment correlation. The results of the analysis show that The Doodle Test has a significant correlation with The Wartegg Zeichen Test so that it can be said to be valid in measuring aspects of personality as measured by The Wartegg Test.
\end{abstract}

Keywords: concurrent validity; correlation; projection test; The Doodle Test; The Wartegg Zeichen Test;

\section{Pendahuluan}


Proyeksi terjadi apabila seseorang melemparkan sebagian dari sesuatu dalam dirinya seperti perasaan, pikiran, dan sentimen kepada sesuatu di luar dirinya, yang bisa berupa obyek, subyek ataupun situasi (Bateman \& Holmes, 1995). Sebagai pelopor teknik proyektif dengan teori psikodinamikanya, Freud menjelaskan bahwa proyeksi merupakan mekanisme pertahanan yang digunakan untuk bertahan melawan dorongan yang mengganggu (Costa, 2017). Dorongan yang mengganggu tersebut bisa berupa nafsu, agresivitas, atau dorongan yang tidak diterima lainnya oleh diri. Dorongan itu masih terekspresikan, namun dengan adanya mekanisme pertahanan diri maka cara mengekspresikannya menggunakan cara yang tidak terlalu mengancam sekaligus mengurangi kecemasan. Freud percaya bahwa sebenarnya mekanisme pertahanan diri ini selalu beroperasi di dalam bawah sadar namun intensitasnya berfluktuasi dan tidak dapat berhenti di dalam kepribadian (Stoddard, 2003). Hal ini yang membuat seseorang tidak menyadari penggunaannya dan seberapa banyak mekanisme pertahanan diri tersebut digunakan.

Teknik proyektif digunakan Freud dalam teknik interpretasi mimpinya, dan kemudian dikembangkan oleh Herman Rorschach di tahun 1921 dengan tes Rorschach dan Murray di tahun 1935 dengan tes TAT (Thematic Apperception Test) untuk mengungkap aspek-aspek kepribadian manusia. Dalam sebuah tes proyeksi, asumsi dasarnya adalah apabila individu dihadapkan pada hal-hal yang ambigu, maka dirinya akan memproyeksikan kepribadiannya melalui jawaban-jawaban terhadap stimulus tersebut (Schultz \& Schultz, 2001). Untuk memproyeksikan hal-hal yang ada dalam diri individu, diperlukan sebuah layar, yaitu alat tes proyeksi itu sendiri yang memiliki stimulus atau gambar tertentu.

Tes proyeksi memberikan stimulus yang artinya tidak segera jelas sehingga mendorong individu untuk memproyeksikan kebutuhan atau nilai-nilai di dalam diri ke dalam respon tes tersebut. Pada tes ini tidak terdapat jawaban yang benar atau salah sehingga menuntut kesimpulan hasil tes yang bersifat luas dan kualitatif sekaligus berakibat lebih subyektif. Kecenderungan untuk subjektif ini dapat diatasi dengan pengetahuan dan pengalaman penggunaan alat tes yang dimiliki oleh asesor yang menggunakan.

The Wartegg Zeichen Test adalah tes menggambar yang menggunakan teknik proyektif yang dibangun pada tahun 1920-an dan 1930-an dipelopori oleh Ehrig Wartegg, seorang psikolog Jerman. The Wartegg Zeichen Test mulai diciptakan dari 1926, namun baru dipublikasikan pertama kali pada 1939. Nama tes ini dahulu dikenal dengan Wartegg Drawing Completion Test, namun sekarang lebih familiar dengan The Wartegg Zeichen Test. Tes ini terdiri atas 8 (delapan) kotak kecil yang berisi bentuk-bentuk gambar yang harus dikembangkan atau dilanjutkan. The Wartegg Zeichen Test menggali aspek-aspek psikologis seseorang dengan menampilkan struktur kepribadian berdasarkan respon yang diberikannya. Hasil tes ini digunakan untuk menganalisis dan mengukur emosi, imajinasi, serta aspek intelektual (Roivanen, 2009). The Wartegg Zeichen Test saat ini masih menjadi andalan dalam tes psikologi 
di Indonesia, karena saat ini masih diyakini mampu mengungkap kepribadian seseorang.

Tabel 1

Indikator Gambar Representasi Fungsi dan Aspek Kepribadian Pada The Wartegg Zeichen Test

\begin{tabular}{ccl}
\hline \multirow{2}{*}{ Emosi } & Outgoing & Animate nature: physiognomy; expansion; curves; casualness \\
\cline { 2 - 3 } Seclusive & $\begin{array}{l}\text { Inanimate Nature, atmosphere; soft lines; symetric abstraction; } \\
\text { asymetric abstraction; shading (both light and dark); parts; } \\
\text { scribbles; schematism. }\end{array}$ \\
\hline \multirow{2}{*}{ Imajinasi } & Combining & Physiognomy; ornaments; style; organization; symetric abstraction \\
\cline { 2 - 3 } Intelektual & Creative & $\begin{array}{l}\text { Expansion; fantasy (including fancy; phantasm and symbolism); } \\
\text { originality; asymetric abstraction; dark shading }\end{array}$ \\
\hline \multirow{2}{*}{ Aktifitas } & Practical & Object (both utility and ornaments) \\
\cline { 2 - 3 } & Speculative & Organization; technical abstraction \\
\cline { 2 - 3 } & Controlled & $\begin{array}{l}\text { Animate nature; movement; fullness; strong pressure; carefulness; } \\
\text { closure duplication; repetition }\end{array}$ \\
\hline $\begin{array}{l}\text { Emptiness; constriction; stright lines; strong pressure; carefulness; } \\
\text { closuplication; repetition }\end{array}$ \\
\hline
\end{tabular}

Memakai konsep grafologi, Andrea Mcnichol menciptakan The Doodle Test. The Doodle Test adalah tes grafis yang bentuknya seperti The Wartegg Zeichen Test dan alat tes ini telah banyak dipakai di berbagai belahan dunia. Dengan alasan berbasis dasar grafologi, tes ini dianggap dapat digunakan oleh praktisi yang tidak mempunyai latar pendidikan psikologi atau pun konseling. Grafologi adalah salah satu cabang ilmu tentang membaca karakter. Manusia selalu tertarik dengan variabilitas manusia dan keunikan individu. Dengan bantuan grafologi seseorang berfokus pada menafsirkan karakter dan kepribadian seseorang dengan menganalisis tulisan tangan. Seorang praktisi dapat menggunakan grafologi untuk menentukan profil dan kepribadian seseorang secara lengkap. Hanya saja, hingga saat ini masih sedikit literatur atau penelitian terkait dengan alat ukur ini.

\section{The Wartegg Zeihen Test (WZT)}

The Wartegg Zeihen Test (WZT) adalah tes menggambar yang dikembangkan pada 1920-an dan 1930-an oleh psikolog Austro-Jerman Ehrig Wartegg. Ia tidak menyebutkan konsep proyeksi pada tesnya, karena beberapa alasan di antaranya kondisi politik yang memanas sehingga menyebabkan ilmu terkait psikoanalisa dan gestalt dilarang saat itu. Bentuk tes terdiri dari kertas A4 berukuran standar memiliki delapan kotak putih, $4 \mathrm{~cm}$ x $4 \mathrm{~cm}$ dalam dua baris dengan latar belakang hitam. Setiap kotak kosong berisi tanda kecil, seperti titik atau garis, yang diberikan sebagai titik awal gambar. Subjek diinstruksikan untuk menyelesaikan delapan gambar, dengan memasukkan tanda yang diberikan ke dalam gambar.

Pemikiran Ehrig Wartegg sendiri dalam menyusun alat ukur ini banyak dipengaruhi oleh teori dan pemikiran psikoanalisis yang ia sandingkan dengan prinsipprinsip Gestalt. Ia mengacu pada teori kepribadian yang dikemukakan oleh Sander (Crisi \& Dentale, 2016) dimana terdapat tiga tipe kepribadian manusia. Pertama adalah 
individu dengan tipe G, yaitu orang yang berpikir secara sintesis dimana mereka lebih menyukai entitas yang lengkap dalam proses psikologis di dalam dirinya. Kedua adalah individu dengan tipe kepribadian E, orang yang berpikir secara analisis dan cenderung lebih memperhatikan detail dan spesifik. Ketiga adalah tipe kepribadian GE yaitu orang yang berpikir analisis sekaligus sintesis.

Ehrig Wartegg menyimpulkan individu dengan ketiga tipe kepribadian yang berbeda tadi akan menggambar dengan hasil yang berbeda. Mereka akan mengeksekusi stimulus pada kotak-kotak di tesnya dengan cara yang berbeda pula. Untuk mengaplikasikan interpretasinya secara lebih mudah, ia kemudian membuat tipe kepribadian yang lebih mendetail dari yang dibuat oleh Sander, yaitu adanya empat dimensi skema kepribadian yang menunjukkan fungsi dasar emosi, imajinasi, intelektual dan aktivitas, yang di kemudian hari digunakan oleh Kinget (Kinget, 1952) untuk dasar interpretasi.

Dicontohkan saja pada kotak ke-6 dimana Ehrig Wartegg memakai stimulus yang merupakan figur Wertheimer (Roivanen, 2009). Respon populer dari kotak ini biasanya adalah usaha untuk menggabungkan dua garis tersebut sehingga menjadi berbentuk persegi panjang. Prinsip Law of Closure dari Gestalt sangat kuat membimbing individu dalam merespon kotak ini dan sangat jarang ditemukan respon garis yang melengkung atau sudut yang membulat.

Menggunakan dasar pemikiran Psikoanalisis dari Jungian, Ehrig Wartegg mendefinisikan kotak ini sebagai kekuatan berlawanan dari perpecahan dan merupakan sebuah kohesi, yang mana ini menyimbolkan kemampuan individu untuk mengintegrasikan emosi dan melakukan kontrol rasional. Dalam The Wartegg Zeichen Test, respon penggambar terhadap stimulus di dalam kotak lambat laun bisa berkembang dari hanya garis-garis sederhana menjadi suatu gambar konmpleks yang utuh. Proses menggambar tersebut dipengaruhi oleh persepsi Gestalt dan pada saat yang sama emosi, nilai-nilai dan motivasi penggambar memainkan peranan yang penting dalam proses "gestaltung" tersebut.

Setelah era perang dunia, penggunaan The Wartegg Zeichen Test berbeda-beda di tiap negara. Adalah dua orang psikolog dari Finland yaitu Takala dan Hakkarainen yang pertama kali mencoba membuat skoring kuantitatif sehingga dapat diselidiki secara empiris dalam sebuah penelitian ilmiah. Penelitian ini menunjukkan bahwa skor pada The Wartegg Zeichen Test berelasi dengan intelektual dan minat pada karir namun belum menunjukkan relasi yang signifikan dengan kondisi kepribadian. Namun demikian alat ini masih terus digunakan dalam setting klinis, sekolah dan industri.

Tahun 1970, Gardziella kemudian membuat manual penggunaan The Wartegg Zeichen Test dengan metode yang sebagian besar merujuk pada ide pemikiran asli dari Wartegg dan juga mengadopsi beberapa modifikasi cara interpretasi yang disarankan oleh (Foley \& Kinget, 1953) serta Lossen dan Schott (Crisi \& Dentale, 2016), terutama terkait urutan gambar dan makna simbol yang muncul pada tiap-tiap kotak. Penginterpretasiannya sendiri bukan berdasarkan pada teori kepribadian tertentu namun 
lebih kepada pengalaman kasus klinis yang selama ini ia amati. Menurutnya, orangorang yang ambisius mengambar garis panjang serupa tangga yang naik dan grafik yang menunjukkan pertumbuhan pada kotak ketiga. Orang yang impulsif akan memulai dari kotak ke-8 sementara orang yang sistematis dan teratur akan mulai dari kotak pertama. Hasil interpretasi dari aspek kualitatif gambar seperti ukuran, tekanan dan banyaknya detail gambar banyak merujuk pada pemikiran tes gambar Draw A Person yang ditulis oleh Machover. Cara interpretasi kualitatif yang digunakan oleh Gardziella ini kemudian yang banyak digunakan oleh banyak klinisi Indonesia di lapangan. Namun demikian hingga saat ini belum ada penelitian yang menunjukkan bahwa interpretasi kualitatif terkait makna simbol di setiap kotak The Wartegg Zeichen Test tersebut cukup valid (Roivainen \& Ruuska, 2005). Selain cara yang dilakukan oleh Gardziella, di Indonesia cara interpretasi juga banyak merujuk pada skoring kuantitatif yang diajukan oleh Kinget (Foley \& Kinget, 1953). Kinget mengajukan sebuah blanko skor untuk memudahkan penilaian kuantitatif yang memang ditujukkan lebih bermanfaat untuk kepentingan penelitian daripada menjadi sebuah alat untuk mendukung pembuatan profil secara kualitatif dalam praktek psikologi di lapangan. Dalam blanko tersebut akan diberikan skor pada bagian isi dari bentuk, tema maupun jenis gambar untuk merepresentasikan sifat-sifat tertentu. Hal ini terkait dengan coretan, abstraksi maupun gambar itu sendiri. Berikut penjelasan bagaimana melihat aspek-aspek tersebut serta jenis gambar seperti apa yang dapat digolongkan pada masing-masing aspek.

\section{The Doodle Test Sebagai Tes Proyeksi}

Gambar coretan adalah tanda yang diproduksi secara spontan tanpa sadar, ketika pikiran seseorang disibukkan dengan sesuatu yang lain daripada hanya peduli dengan proses menggambar itu sendiri (Watson, 2008). Proses yang terjadi merupakan aktivitas yang sadar secara parsial. Dengan kata lain, menggambar coretan dipahami sebagai fenomena subyektif yang melibatkan alam bawah sadar. Mcnichol juga menjelaskan bahwa melakukan doodling atau mencorat-coret dianggap bukan hanya sekedar pengisi waktu luang atau kebosanan namun juga merupakan representasi dari pikiran tidak sadar dan diistilahkan sebagai DNA bagi pemikiran individu (Mcnichol \& Nelson, 1994). Seperti halnya DNA, hasil coretan dianggap sebagai representasi unik dan tidak sama untuk masing-masing orang. Dengan melihat hasil gambar corat-coret individu, maka dapat diketahui kecenderungan kepribadian, perilaku dasar dan kebutuhan individu tersebut.

Karena merupakan representasi dari alam bawah sadar, maka kemudian sangat mungkin untuk menjelaskan proses emosi kognitif yang mendasari munculnya perilaku menggambar coretan yang dilakukan oleh individu. Psikologi gestalt menjelaskan bagaimana system visual bekerja mempengaruhi munculnya persepsi tertentu. Dalam konsep visual grouping, misalnya, pola yang mendapatkan penekanan kuat akan lebih diutamakan daripada pola yang lemah. Prinsip ini juga bertujuan untuk menyeleksi tanda-tanda visual yang dianggap menggangu (noise). Tanpa adanya tanda visual yang 
mengganggu maka akan ditemukan hubungan antar tanda-tanda visual yang memiliki keterkaitan. Kerja system visual yang kemudian mengirimkan keberhasilan melakukan pengelompokkan tersebut serta merta akan menyampaikan rasa puas kepada system limbik sehingga memunculkan sensasi menyenangkan dalam pengalaman estetis ini.

Jika perilaku mencoret-coret adalah fenomena subyektif yang melibatkan alam bawah sadar, maka munculnya bentuk-bentuk tertentu dan elemen-elemen dasar tertentu mungkin muncul sebagai hasil dari suatu hal yang penting dan mendasar bagi individu. Perilaku memproduksi gambar coretan didasari oleh preferensi individu untuk menghasilkan tanda tertentu. Walaupun perilaku mencoret-coret dianggap sebagai proses yang subyektif, secara parsial sadar dan stimulus atau aspirasi bentuk coretan digerakkan oleh internal individu, namun ternyata perilaku ini juga merupakan sebuah bentuk ekspresi yang dilakukan individu untuk membahasakan situasi atau pengalamannya berinteraksi dengan lingkungan luar dirinya. Misalnya motif-motif geometric yang dihasilkan pada coretan mungkin saja didapat dari ingatan individu terhadap bentuk dari garis, pola atau bentuk dari dunia fisik di luar dirinya. Dengan demikian maka dapat dikatakan bahwa hasil coretan merupakan gabungan dari dunia luar dan dunia dalam diri penggambar yang saling berinteraksi (Watson, 2008).

Menggambar coretan bukan hanya dilakukan dengan mencoret bebas pada kertas kosong, tapi dapat juga terjadi ketika individu merespon dari tanda atau stimulus tertentu yang dijadikan sebagai medium. Melihat tanda stimulus pada kertas lalu melakukan coretan tambahan pada tanda tersebut merupakan respon otomatis yang terjadi pada system visual manusia yang enggan membiarkan suatu tanda tampak ambigu dan tidak bermakna (Davis, 1986).

Andrea Mcnichol merupakan salah satu grapologis yang menciptakan alat ukur kepribadian bernama The Doodle Test. Tes sederhana ini berisi 12 kotak dimana 11 kotak berisi stimulus tanda tertentu serta 1 kotak yang kosong. Tes ini sangat menyerupai Tes Wartegg namun berbeda pada bentuk stimulus dan jumlah kotaknya. Berbeda dengan Ehrig Wartegg yang menyatakan secara terang benderang mengunakan prinsip Gestalt yang dipadukan dengan Psikoanalisis, Mcnichol menggunakan dasar teori grafologi pada sebagian banyak cara interpretasinya. Grafologi adalah ilmu yang mempelajari seluruh tarikan gerakan ketika seseorang menggoreskan alat tulisnya, tidak hanya terbatas pada tulisan saja. Seorang grafolog mempelajari coretan, gambar, pahatan, dan lukisan untuk mendapatkan wawasan tentang kondisi fisik, mental, dan emosional dari pembuatnya. Bagi Andrea Mcnichol goresan tangan bukan hanya semata kerja tangan, namun juga menggambarkan bagaimana otak bekerja (Mcnichol \& Nelson, 1994).

Grafologi tidak ditanggapi serius di Amerika Serikat karena pada tahun 1960an sempat muncul sebuah metode yaitu Graphoanalysis, dimana mereka menjustifikasi dapat mengenali gangguan fisik dan psikologis individu hanya berdasarkan pemeriksaan sederhana dengan melihat dari cara orang menuliskan satu huruf tertentu. Tentu saja ilmu yang mengklaim berdasarkan pengamatan yang dangkal seperti ini akan 
dideskreditkan sehingga menyebabkan ilmu yang terkait dengan tulisan tangan ditolak sebagai alat diagnostic. Berbeda dengan metode graphoanalysis, grafologi dikembangkan oleh psikiater di Eropa dan tidak berdasarkan teori psikologi popular seperti yang terjadi di Amerika (Scanlon \& Mauro, 1992). Tokoh seperti Jung dan Freud mempelajarinya dengan mendalam dan mereka hanya memberikan perhatian yang sedikit pada huruf-huruf secara individual. Cara kerjanya lebih komprehensif dimana keseluruhan tulisan dilihat dari letak, bentuk garis, dan seberapa tingkat kejelasan penulisan. Kedua tokoh ini berkesimpulan bahwa hasil goresan tangan adalah jendela bagi pemikiran sadar dan bawah sadar individu. Keduanya pun mengakui adanya pengaruh ketidaksadaran yang berisi emosi, nilai dan kebutuhan dari seorang penggambar ketika memproduksi sebuah coretan.

Dalam The Doodle Test, McNichol menjelaskan bahwa semakin banyak coretan bergambar manusia dalam hasil tes menunjukkan semakin tinggi tingkat minat social individu tersebut (Mcnichol, 1993). Hal ini sejalan dengan interpretasi The Wartegg Zeichen Test dimana jumlah gambar manusia yang lebih tinggi daripada rata-rata umumnya ditafsirkan sebagai tanda kemampuan bersosialisasi (Roivanen, 2009). Andrea McNichol sendiri tidak pernah menciptakan sistem skoring kuantitatif sebagaimana The Wartegg Zeichen Test. Interpretasinya lebih kepada interpretasi simbol-simbol yang muncul dan cara individu mengeksekusi seperti garis, duplikasi, simetris dan lain-lain, dengan cara pandang yang hampir menyerupai The Wartegg Zeichen Test. Rujukan hasil penelitian dan kajian terkait dasar teori yang digunakan oleh McNichol dalam menginterpretasi secara kualitatif tiap-tiap makna simbol di kotak sangat minim. Ia mengakui bahwa interpretasi tersebut berdasarkan pengalamannya di lapangan sebagi ahli forensik dan pemahamannya terkait makna simbol yang menyerupai makna simbol pada pemikiran psikoanalisis. Sejauh ini belum ada penelitian uji psikometrik terkait dengan The Doodle Test walaupun beberapa pihak telah menerapkannya untuk praktek di lapangan baik sebagai alat ukur seleksi karyawan di bidang industri dan organisasi maupun pada bidang lain seperti Pendidikan dan Klinis.

\section{Validitas Alat Ukur}

Alat ukur dikatakan valid ketika alat ukur tersebut mengukur apa yang seharusnya diukur. Atau, dengan kata lain, ketika suatu alat ukur dapat secara akurat mengukur variabel yang ditentukan maka alat ukur itu dianggap valid untuk variabel tertentu (Muijs, 2012). Pentingnya aspek ini karena alat ukur yang valid akan meningkatkan transparansi, dan mengurangi peluang untuk memasukkan bias penelitian dalam penelitian kualitatif (Mohajan, 2017). Validitas alat ukur dibagi menjadi beberapa jenis, diantaranya: validitas kriteria (yang mencakup validitas konkuren dan prediktif) dan validitas konstruk (yang mencakup validitas konvergen, divergen, faktorial, dan diskriminan) (Bannigan \& Watson, 2009). Adapun, validitas yang digunakan dalam penelitian ini adalah validitas konkuren yang merupakan bagian dari validitas kriteria. 
Validitas kriteria atau dikenal juga dengan validitas konkret adalah jenis validitas yang mengukur seberapa baik suatu alat ukur memprediksi hasil untuk ukuran lain (Taherdoost, 2018). Alat ukur yang memenuhi validitas jenis ini dapat digunakan untuk memprediksi kinerja atau perilaku pada situasi lain (masa lalu, sekarang, atau masa depan). Adapun validitas konkuren adalah sejauh mana hasil dari suatu alat ukur sesuai dengan hasil dari alat ukur lain dari konstruksi yang sama atau serupa (Zheng \& de Jong, 2011). Sedangkan dalam definisi lain, McDowell (2009) menyebutkan bahwa validitas konkuren adalah validitas yang menilai sejauh mana suatu alat ukur berkorelasi dengan 'standar emas' (gold standard). Standar emas yang dipakai adalah alat ukur serupa dengan skala yang saat ini diterima untuk mengukur konstruk yang tengah diukur. Validitas konkuren dapat menguji keakuratan alat ukur secara lengkap (utuh) ataupun setiap butir pertanyaan.

Prosedur perhitungan validitas konkuren yang dijelaskan oleh Bannigan \& Watson (2009), adalah dengan melakukan perhitungan korelasi skor alat ukur yang diteliti dengan skor dari alat ukur gold standard. Akan tetapi, perlu diperhatikan bahwa alat ukur gold standard memiliki reliabilitas atau validitas yang telah teruji secara psikometris. Di Indonesia pernah dilakukan uji reliabilitas terhadap tes wartegg yang menunjukkan bahwa tes Wartegg sangat reliabel, dimana nilai koefisiensi yang diperoleh menunjukkan nilai koefisiensi >0.8 (Suhapti, 1989). Sementara itu dalam penelitian terdahulu juga didapatkan bahwa melalui metode studi literatur dan metanalisis reliabilitas dan validitas didapatkan bahwa tes ini memiliki reliabilitas interskor dan validitas yang tinggi juga (Grønnerød \& Grønnerød, 2012).

Berdasarkan uraian tersebut, maka penelitian kali ini bertujuan untuk melakukan uji validitas konkuren terhadap The Doodle Test dengan menggunakan validitas konkuren dengan melihat korelasinya dengan alat tes serupa yang sudah ada yaitu The Wartegg Zeichen Test. Diharapkan hasil penelitian ini dapat menambah khasanah keilmuan di bidang psikologi terkait tes gambar proyektif serta menjadi acuan bagi para praktisi di lapangan dalam mempertimbangkan penggunaan tes gambar proyektif.

\section{Metode}

Penelitian validitas tes proyeksi The Doodle Test melibatkan sampel penilitian dengan jumlah peserta sebanyak 103 partisipan dengan jenis kelamin pria sebanyak 53 orang dan jenis kelamin wanita sebanyak 50 orang serta berusia 18-35 tahun.

Adapun prosedur penelitian ini dilakukan dengan cara memberikan dua tes pada waktu yang bersamaan, yaitu The Doodle Test dan The Wartegg Zeichen Test. Hasil tes kemudian dilakukan pemberian skor mengacu pada cara pemberian skor sebagaimana yang diajukan oleh Kinget (Kinget, 1952).

Proses skoring dilakukan oleh dua orang psikolog dengan mendiskusikan gambar sehingga pada akhirnya diperoleh kesepakatan skor. Agar prosedur pemberian skor serta analisisnya menjadi lebih mudah, dalam tes ini digunakan blanko 
skoring (scoring blank). Blanko skoring terbagi menjadi dua bagian yang saling berhadapan. Di sebelah sisi-sisinya adalah daftar aspek variable yang termasuk bagian kuantitatif dalam diagnosis. Angka-angka pada lajur atas menunjuk pada nomor gambar. Satu poin diberikan bagi representasi yang lemah dua poin bagi representasi yang kuat, dan tiga poin bagi representasi yang sangat kuat. Untuk meningkatkan objektivitas dan akurasi penilaian, setiap langkah pada skala tiga poin terebut dibelah menjadi dua atau adanya nilai 0.5 . Bila pemberian skor telah selesai, maka skor yang diperoleh (kedua belas gambar pada The Doodle Test dan kedelapan gambar pada The Wartegg Zeichen Test) setiap kriteria dijumlahkan dan jumlahnya dituliskan di samping kriteria yang bersangkutan yaitu di dalam kolom "total score".

Instrumen penelitian ini adalah The Doodle Test yang diciptakan oleh Andrea McNichol. Tes ini terdiri dari 12 kotak, di mana masing-masing kotak berisi tandatanda tertentu. Subyek diminta untuk menggunakan tanda tersebut menjadi bagian dari gambarnya. Selain itu, penelitian ini juga menggunakan The Wartegg Zeichen Test, seperti halnya The Doodle Test, tes yang diciptakan oleh Ehrig Warteeg terdiri dari 8 (delapan) kotak, dengan masing-masing kotak terdapat tanda-tanda tertentu.

Penelitian ini menerapkan metode penelitian kuantitatif, yaitu berkaitan dengan mengukur dan menganalisis variabel dalam memperoleh suatu hasil dengan melibatkan analisis data numerik, yang menggunakan teknik statistik tertentu untuk menjawab suatu persoalan (Apuke, 2017). Untuk teknik statistik yang digunakan adalah uji korelasi Pearson's Product Moment. Teknik Pearson's Product Moment mengukur kekuatan, arah (positif atau negatif), dan probabilitas hubungan linier antara dua variabel interval atau rasio yang memiliki rentang nilai antara -1 hingga +1 (Chee \& Queen, 2018). Lebih jauh, Chee dan Queen (2018) menyebutkan bahwa teknik ini merupakan cara sederhana untuk menilai hubungan antara dua variabel, yaitu apakah mereka berbagi varians, jika hubungannya positif atau negatif, dan sejauh mana mereka berkorelasi. Dalam penelitian ini, analisis korelasi dilakukan antara skor per fungsi maupun aspek dari The Doodle Test dan The Wartegg Zeichen Test. Dengan demikian dapat dilihat sejauh mana skor kedua alat tes memiliki hubungan sebagai indikator yang menunjukkan kesamaan konstruksi. Ketika skor yang diperoleh dari dua instrumen berbeda sama sangat berkorelasi, maka ini adalah kondisi di mana dua variabel yang diukur secara terpisah memiliki hubungan satu sama lain (Straub, 1989). Dengan kata lain, keduanya mengukur konsep yang sama.

\section{Hasil}

Dalam penelitian ini telah dilakukan uji validitas pada tes proyeksi gambar berstimulus The Doodle Test dengan menggunakan teknik korelasi product moment dengan skor The Wartegg Zeichen Test. Analisis validitias dilakukan dengan berdasarkan pada sampel penelitian yang berukuran 103 partisipan yang terdiri dari 53 pria dan 50 wanita berusia 18-35 tahun. 
Hasil uji validitas konkuren dengan teknik korelasi product moment menunjukkan bahwa terdapat hubungan antara skor The Doodle Test dan skor The Wartegg Zeichen Test dengan p-value $<0.05$. Pada tabel 2 dapat diperhatikan bahwa koefisien korelasi yang memiliki p-value $<0.05$ ditandai dengan $*$.

Tabel 2

Koefisien Korelasi Product Moment Skor The Doodle Test dan Skor The Wartegg Zeichen Test Level Fungsi

The Doodle Test

EMOTION IMAGINATION INTELLECT ACTIVITY

\begin{tabular}{llllll}
\hline \multirow{2}{*}{$\begin{array}{l}\text { The } \\
\text { Wartegg }\end{array}$} & EMOTION & $0.332^{*}$ & $0.270^{*}$ & 0.005 & 0.190 \\
\cline { 2 - 6 } $\begin{array}{l}\text { Zeichen } \\
\text { Test }\end{array}$ & IMAGINATION & 0.170 & $0.252^{*}$ & 0.101 & 0.130 \\
\cline { 2 - 6 } & INTELLECT & -0.010 & 0.139 & $-0.200 *$ & 0.005 \\
\cline { 2 - 6 } & ACTIVITY & $0.348 *$ & 0.173 & 0.043 & $0.300^{*}$ \\
\hline
\end{tabular}

*Koefiesien korelasi signifikan ( -value < 0.05$)$

Seluruh koefisien korelasi antar faktor menunjukkan signifikansi. Fungsi Emotion, Imagination dan Activity memiliki korelasi yang signifikan di antara kedua alat tes. Artinya, pada subyek yang memiliki skor tinggi pada fungsi Emotion, Imagination dan Activity pada The Doodle Test akan menunjukkan skor yang tinggi pula pada fungsi tersebut di alat tes The Wartegg Zeichen Test. Sementara itu, faktor Intellect memiliki korelasi yang signifikan walaupun bernilai negatif, yang artinya apabila subyek memiliki skor yang tinggi pada The Doodle Test maka hasil sebaliknya akan memiliki skor yang rendah pada alat tes The Wartegg Zeichen Test.

Tabel 3

Koefisien Korelasi Product Moment Skor The Doodle Test dan Skor The Wartegg Zeichen Test Level Aspek

\begin{tabular}{lcccccccc}
\hline \multirow{2}{*}{$\begin{array}{l}\text { The Wartegg } \\
\text { Zeichen Test }\end{array}$} & Open & Seclucive & $\begin{array}{c}\text { Combi- } \\
\text { nation }\end{array}$ & Creative & Practical & $\begin{array}{c}\text { Specu- } \\
\text { lative }\end{array}$ & $\begin{array}{c}\text { Dynamic } \\
\text { Controlle } \\
\text { d }\end{array}$ \\
\cline { 2 - 9 } Open & $0.277^{*}$ & 0.104 & -0.040 & $0.227^{*}$ & -0.095 & -0.124 & 0.171 & -0.089 \\
\hline Seclucive & $0.316^{*}$ & $0.194^{*}$ & 0.120 & $0.222^{*}$ & $0.261^{*}$ & -0.014 & 0.165 & 0.148 \\
\hline Combination & $0.202^{*}$ & -0.084 & 0.148 & 0.075 & $0.225^{*}$ & -0.032 & 0.159 & -0.007 \\
\hline Creative & $0.367 *$ & 0.016 & 0.066 & $0.295^{*}$ & 0.044 & 0.037 & $0.196^{*}$ & -0.110 \\
\hline Practical & -0.149 & -0.072 & -0.192 & -0.022 & 0.095 & $-0.394^{*}$ & -0.027 & -0.057 \\
\hline Speculative & 0.154 & 0.044 & 0.055 & $0.388^{*}$ & 0.128 & $-0.212^{*}$ & $0.195^{*}$ & -0.049 \\
\hline Dynamic & $0.342^{*}$ & 0.142 & -0.087 & 0.152 & 0.024 & $-0.220^{*}$ & $0.275^{*}$ & -0.019 \\
\hline Controlled & $0.243^{*}$ & 0.165 & 0.191 & 0.111 & 0.188 & $0.204 *$ & 0.006 & $0.494 *$ \\
\hline$*$ Koefiesien korelasi signifikan $(p-v a l u e<0.05)$ & & & & &
\end{tabular}


Berdasarkan tabel 3 di atas, terlihat sejumlah korelasi yang signifikan ( $p$-value $<0.05)$ diantaranya adalah aspek-aspek yang linear pada kedua alat tes tersebut.

\section{Pembahasan}

Pengujian korelasi antara skor The Doodle Test dan skor The Wartegg Zeichen Test dengan teknik korelasi product moment menunjukkan hasil yang signifikan dengan $\mathrm{p}$-value $<0.05$. Artinya, terdapat hubungan yang signifikan antara fungsi kepribadian yang diukur pada The Doodle Test dan The Wartegg Zeichen Test atau dengan kata lain keduanya mengukur fungsi-fungsi kepribadian yang sama. Menurut Zheng dan de Jong (2011), sebuah alat ukur dapat dikatakan valid apabila memiliki korelasi yang signifikan dengan alat ukur lain yang memiliki konstruksi yang sama atau serupa. Pengujian validitas dilakukan dengan cara mencari korelasi kedua alat ukur secara keseluruhan, apabila hasil korelasinya menunjukkan hasil signifikan, maka alat ukur yang diuji validitasnya sebanding dengan validitas alat ukur yang menjadi kriterianya (Bannigan dan Watson, 2009). Berdasarkan hasil analisis data dapat dilihat bahwa skor pada keempat fungsi yaitu baik Emotion, Imagination, Intellect, dan Activity pada The Doodle Test memiliki hubungan signifikan masing-masing dengan skor keempat fungsi pada The Wartegg Zeichen Test. Oleh karena itu, sebagai alat tes proyeksi gambar, The Doodle Test cukup valid digunakan sebagai metode alternatif dalam mengungkap kepribadian sebagaimana The Wartegg Zeichen Test.

Seluruh koefisien korelasi yang signifikan bernilai positif kecuali untuk hubungan antara skor fungsi Intellect pada The Doodle Test dan fungsi Intellect pada The Wartegg Zeichen Test. Hal ini menunjukkan adanya hubungan yang berlawanan arah antara kedua dimensi tersebut. Dengan kata lain, saat skor dimensi Intellect pada The Doodle Test semakin tinggi, maka skor dimensi Intellect pada The Wartegg Zeichen Test justru semakin rendah, dan berlaku sebaliknya. Apabila dilihat lebih mendalam, hasil korelasi yang berlawanan arah ini terdapat pada aspek kepribadian Speculative, yaitu kecenderungan individu untuk mengutamakan prinsip-prinsip, penalaran, teori dan hal yang tidak praktis. Pada aspek kepribadian ini, skor dilihat dari banyaknya individu melakukan eksekusi gambar secara organize dan berbentuk technical abstraction.

Selain adanya hubungan keempat fungsi pada kedua alat ukur tersebut, ditemukan juga bahwa skor fungsi Emotion yaitu aspek Open-Emotion pada The Doodle Test memiliki hubungan yang signifikan dengan skor fungsi Dynamic-Activity pada The Wartegg Zeichen Test. Hal ini sangat mungkin terjadi karena apabila merujuk pada penjelasan terkait indikator gambar maka keduanya melihat eksekusi gambar Animate nature serta expansion yang memiliki keterkaitan dengan indikator fullness. Begitu juga ketika ditemukan bahwa skor Imagination pada The Doodle Test memiliki hubungan yang signifikan dengan skor fungsi Emotion pada The Wartegg Zeichen Test. Keduanya mengukur seberapa banyak individu mengeksekusi gambar secara expansion dan abstraction. 
Berdasarkan analisis koefisien korelasi product moment, terlihat sejumlah korelasi yang signifikan ( $p$-value $<0.05)$ diantaranya adalah aspek-aspek yang linear pada kedua alat tes, yaitu aspek Seclusive, Creative, Dynamic serta aspek Controlled. Di samping pasangan aspek yang serupa dari kedua instrumen, terdapat aspek yang tidak serupa namun memiliki korelasi yang signifikan, yaitu: aspek Open pada The Doodle Test dengan aspek Seclusive, Combination, Creative, Dyanmic, dan Controled pada The Wartegg Zeichen Test; aspek Creative pada The Doodle Test dengan aspek Open, Seclusive, dan Speculative pada The Wartegg Zeichen Test aspek Practical pada The Doodle Test dengan aspek Seclusive dan Combination The Wartegg Zeichen Test; dan aspek Speculative pada The Doodle Test dengan aspek Practical, Dynamic, Controlled pada The Wartegg Zeichen Test, serta aspek Dynamic The Doodle Test dengan aspek Creative dan Speculative pada The Wartegg Zeichen Test. Korelasi yang signifikan antar aspek ini menunjukkan bahwa The Doodle Test memiliki konstruksi pengukuran yang serupa dengan The Wartegg Zeichen Test.

\section{Kesimpulan}

Merujuk pada hasil dan pembahasan pada bagian sebelumnya maka dapat disimpulkan bahwa The Doodle Test valid digunakan sebagai metode alternatif dalam mengungkap kepribadian dalam bentuk alat tes gambar proyeksi sebagaimana The Wartegg Zeichen Test. Hasil korelasi yang signifikan antar fungsi dan aspek kepribadian ini menunjukkan bahwa The Doodle Test memiliki konstruksi pengukuran yang serupa dengan The Wartegg Zeichen Test.

Keempat fungsi yaitu Emotion, Creativity, Activity dan Intellect memiliki korelasi yang signifikan. Fungsi Intelect memiliki korelasi signifikan yang negatif antar tes. Selain itu juga, terdapat korelasi yang signifikan antara aspek-aspek pada The Doodle Test dengan aspek-aspek pada The Wartegg Zeichen Test, dan korelasi ini terjadi tidak hanya pada aspek yang sama namun juga antar aspek yang berbeda. Hal ini dimungkinkan terjadi karena keduanya merupakan alat ukur dengan teknik proyeksi gambar berstimulus yang bentuk stimulusnya saling menyerupai dan menggugah respon pada area yang sama. Selain itu, keduanya juga memiliki cara pengadministrasian yang sama. Diperlukan penelitian lebih lanjut untuk melihat keterkaitan interpretasi kualitatif, terutama untuk tiap-tiap kotak stimulus, yang dimiliki oleh the The Wartegg Zeichen Test dan The Doodle Test. Hal ini diperlukan mengingat hasil interpretasi kuantitatif merupakan sebuah perkiraan saja untuk memudahkan interpreter mendapatkan hasil interpretasi yang cepat dan objektif, sementara untuk meningkatkan komprehensivitas profil individu dibutuhkan interpretasi yang kualitatif.

\section{Referensi}

Apuke, O. D. (2017). Quantitative Research Methods : A Synopsis Approach. Kuwait 
Chapter of Arabian Journal of Business and Management Review, 6(11), 40-47. https://doi.org/10.12816/0040336

Bannigan, K., \& Watson, R. (2009). Reliability and validity in a nutshell [Electronic Version]. Journal of Clinical Nursing. https://doi.org/10.1111/j.13652702.2009.02939.x

Bateman, A., \& Holmes, J. (1995). Introduction to Psychoanalysis. In Introduction to Psychoanalysis. https://doi.org/10.4324/9780203298398

Chee, J. D., \& Queen, T. (2018). Pearson's Product-Moment Correlation : Sample Analysis Pearson's Running head: PEARSON 'S PRODUCT MOMENT CORRELATION Pearson's Product Moment Correlation : Sample Analysis Jennifer Chee University of Hawaii at M à noa School of Nursing. January 2013.

Costa, R. M. (2017). Projection (Defense Mechanism). In V. Zeigler-Hill \& T. K. Shackelford (Ed.), Encyclopedia of Personality and Individual Differences (hal. 1-3). Springer International Publishing. https://doi.org/10.1007/978-3-31928099-8_1413-1

Crisi, A., \& Dentale, F. (2016). The wartegg drawing completion test: Inter-rater agreement and criterion validity of three new scoring categories. International Journal of Psychology and Psychological Therapy.

Davis, W. (1986). The Origins of Image Making. Current Anthropology. https://doi.org/10.1086/203422

Foley, J. P., \& Kinget, C. M. (1953). The Drawing Completion Test: A Projective Technique for the Investigation of Personality. The American Journal of Psychology. https://doi.org/10.2307/1418982

Grønnerød, J. S., \& Grønnerød, C. (2012). The Wartegg Zeichen Test: A literature overview and a meta-analysis of reliability and validity. Psychological Assessment. https://doi.org/10.1037/a0026100

Kinget, G. M. (1952). The Drawing-Completion Test; A projective technique for the investigation of personality. Grune \& Stratton.

McDowell, I. (2009). Measuring Health: A guide to rating scales and questionnaires. In Measuring Health: A Guide to Rating Scales and Questionnaires. https://doi.org/10.1093/acprof:oso/9780195165678.001.0001

Mcnichol, A. (1993). What do your Doodles Reveal; Take The Doodle Test with graphologist Andrea Mcnichol. Mcnichol-Nelson Graphology Institute. Inc.

Mcnichol, A., \& Nelson, J. A. (1994). Handwriting Analysis : Putting It to Workfor You (First Edit). McGraw-Hill Education.

Mohajan, H. K. (2017). Two Criteria for Good Measurements in Research: Validity and Reliability. Annals of Spiru Haret University. Economic Series, 17(4), 59-82. 
https://doi.org/10.26458/1746

Muijs, D. (2012). Introduction to Quantitative Research. In Doing Quantitative Research in Education with SPSS. https://doi.org/10.4135/9781849209014.n1

Roivainen, E., \& Ruuska, P. (2005). The Use of Projective Drawings to Assess Alexithymia. European Journal of Psychological Assessment. https://doi.org/10.1027/1015-5759.21.3.199

Roivanen, E. (2009). A brief history of the Wartegg Drawing test. Gestalt Theory, $31(1), 55-71$.

Scanlon, M., \& Mauro, J. (1992). The Lowdown on Handwriting Analysis. Psychology Today.

Schultz, D. P., \& Schultz, S. E. (2001). Theories of personality (7th ed.). In Theories of personality (7th ed.).

Stoddard, D. A. (2003). A Comparison of the Emotional Indicators on the House-TreePerson Drawings and the KineticHouse-Tree-Person Drawing. Andrews University.

Straub, D. W. (1989). Validating instruments in MIS research. MIS Quarterly: Management Information Systems. https://doi.org/10.2307/248922

Suhapti, R. (1989). Reliabilitas Tes Wartegg.

Taherdoost, H. (2018). Validity and Reliability of the Research Instrument; How to Test the Validation of a Questionnaire/Survey in a Research. SSRN Electronic Journal, January 2016. https://doi.org/10.2139/ssrn.3205040

Watson, B. (2008). Oodles of doodles?: doodling behaviour and its implications for understanding palaeoarts. Rock Art Research, 25(1), 35-60.

Zheng, Y., \& de Jong, H. a. L. J. (2011). Establishing construct and concurrent validity of Pearson Test of English Academic. March, 1-43. http://www.pearsonpte.com/research/Documents/RN_EstablishingConstructAnd ConcurrentValidityOfPTEAcademic_2011.pdf 